\title{
Editorial
}

\section{Celebrating ten years}

Place Branding and Public Diplomacy (2015) 11, 97-100. doi:10.1057/pb.2015.7

The title of this editorial is slightly misleading as nothing much in the nature of celebration has occurred since the journal moved into its 11 th volume, but we did not want to let this anniversary pass without any reflection. We thought it about time to look at its progress in terms of online circulation, since Simon Anholt successfully launched the journal in November 2004. Unfortunately, Palgrave has only been collecting webstats since 2009 , so we'll share with you some insights into the journal's online usage for the last 5 years.

The following metrics are reported:

Visit - An interaction a unique visitor has with the Website over a specified period of time or activity. Consequently, it is a series of page views, beginning when a visitor's browser requests the first page from the server and ending when the visitor leaves the site or remains idle beyond the idle-time limit.

Page Views - Views or page views are generally defined as a request to load a single page of a Website.

Article Views - A request to view an article page - we cannot distinguish between successful and non successful requests, that is, this figure is the total number of attempts to access an article (also by non-subscribers).

Figure 1 shows the trend line of Website visits, page views and article views for the period 2010-2014. It clearly reflects the growing success of the journal, doubling the visits and page views and quadrupling the article views over a period of 5 years. This means that increasingly people are able to find us and know what they are looking for (that is, more article views per visit on average). Figure 2 shows the proportion of visits per country over the 2009-2014 period, which reflects quite a nice geographical spread of readership.

Table 1 shows the 50 papers that generated most article views between 2010 and 2014, representing 57 per cent (138 575) of all (242 681) article views. For a fair comparison, papers are categorised as open access or paid articles and then ranked according to the average quarterly views the paper generated since publication (that is, total article views 2010-2014 divided by number of issues published since publication of the article). In both rankings, the highest ranked papers (Dos Santos and Campo, 2014 and Zenker, 2014) have been given a somewhat unfair advantage as usually the number of article views peaks in the first year of publication and hence, the quantity of average quarterly views is relatively high for these recent papers, compared with older papers for which the initial high volume of views is averaged out in the quarterly stats across multiple years.

Nevertheless, needless to say, Dos Santos and Campo (2014) and Zenker (2014) are some of the best performing papers of 2014. Lastly, what is also noteworthy is that Nuttavuthisit's 2007 paper 'Branding Thailand: Correcting the negative image of sex tourism' continues to perform well. Hence, in conclusion, it seems that in place branding and public diplomacy, as in so much in life, sex sells.

Robert Govers Independent advisor, scholar and author on Place Branding E-mail: rgovers@rgovers.com 


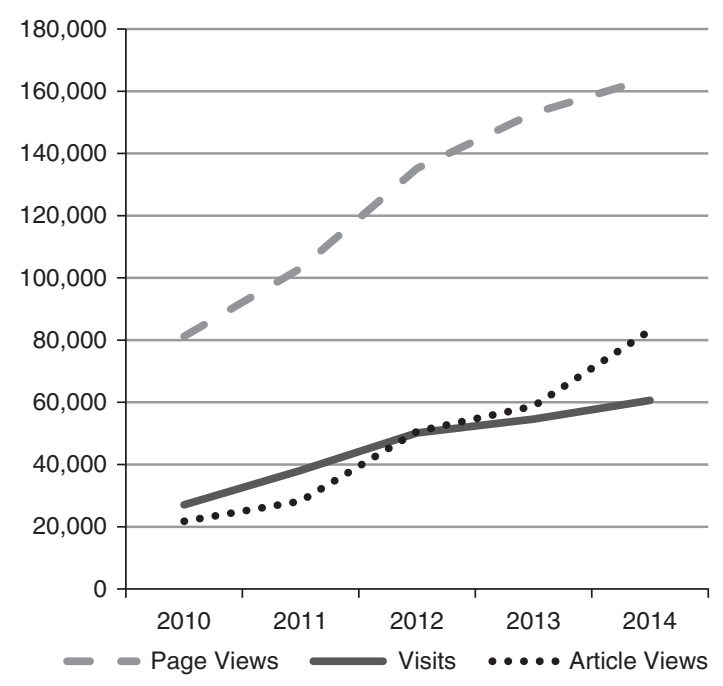

Figure 1: Five year trend lines of visits and views.

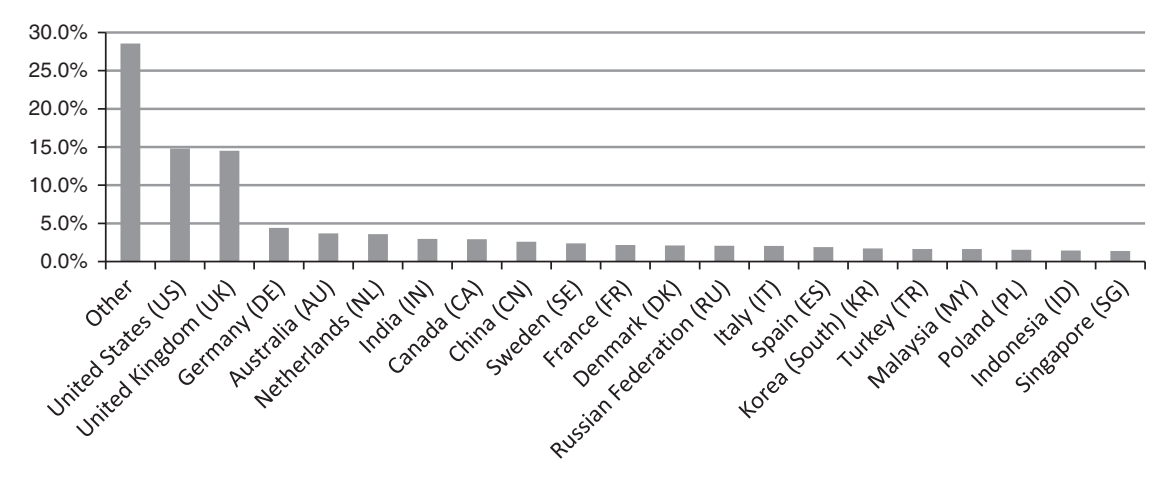

Figure 2: Percentage of visits per country 2009-2014. 
Table 1: Fifty papers with most article views since 2010, ranked based on average quarterly views since publication (total article views 2010-2014 divided by number of issues since publication)

\begin{tabular}{|c|c|c|c|c|c|c|c|}
\hline Rank & $\begin{array}{l}\text { Article title (papers that are/were } \\
\text { published in open access) }\end{array}$ & Author & Year & Volume & Number & $\begin{array}{l}\text { Quarterly } \\
\text { views }\end{array}$ & $\begin{array}{l}\text { Total } \\
\text { views }\end{array}$ \\
\hline 1 & $\begin{array}{l}\text { Destination branding: A reflective } \\
\text { analysis of Brand Cape Verde }\end{array}$ & Dos Santos and Campo & 2014 & 10 & 1 & 835 & 2505 \\
\hline 2 & $\begin{array}{l}\text { Branding Thailand: Correcting the } \\
\text { negative image of sex tourism }\end{array}$ & Nuttavuthisit & 2007 & 3 & 1 & 653 & 13067 \\
\hline 3 & Place branding: Is it marketing, or isn't it? & Anholt & 2008 & 4 & 1 & 579 & 11583 \\
\hline 4 & $\begin{array}{l}\text { An analysis of terminology use in place } \\
\text { branding }\end{array}$ & Hanna and Rowley & 2008 & 4 & 1 & 483 & 9662 \\
\hline 5 & $\begin{array}{l}\text { The role and challenges of country } \\
\text { branding in transition countries: The } \\
\text { Central and Eastern European } \\
\text { experience }\end{array}$ & Szondi & 2007 & 3 & 1 & 430 & 8599 \\
\hline 6 & $\begin{array}{l}\text { Why place branding is not about logos } \\
\text { and slogans }\end{array}$ & Govers & 2013 & 9 & 2 & 323 & 1939 \\
\hline 7 & $\begin{array}{l}\text { Brand China: Using the } 2008 \text { Olympic } \\
\text { Games to enhance China's image }\end{array}$ & Berkowitz et al & 2007 & 3 & 2 & 271 & 5422 \\
\hline 8 & $\begin{array}{l}\text { Attitudes towards American brands and } \\
\text { Brand America }\end{array}$ & Hamilton et al & 2007 & 3 & 3 & 265 & 5296 \\
\hline 9 & $\begin{array}{l}\text { Developing brands and emerging } \\
\text { markets: An empirical application }\end{array}$ & Thomas and Zerrillo & 2007 & 3 & 1 & 264 & 5283 \\
\hline 10 & $\begin{array}{l}\text { WikiLeaks, public diplomacy } 2.0 \text { and the } \\
\text { state of digital public diplomacy }\end{array}$ & Cull & 2011 & 7 & 1 & 264 & 3954 \\
\hline 11 & $\begin{array}{l}\text { Brand Dubai and its competitors in the } \\
\text { Middle East: An image and reputation } \\
\text { analysis }\end{array}$ & Govers & 2012 & 8 & 1 & 236 & 2594 \\
\hline 12 & $\begin{array}{l}\text { Brands and national image: An } \\
\text { exploration of inverse country-of-origin } \\
\text { effect }\end{array}$ & White & 2012 & 8 & 2 & 230 & 2296 \\
\hline 13 & $\begin{array}{l}\text { Place branding sports: Strategies for } \\
\text { differentiating emerging, transitional, } \\
\text { negatively viewed and newly } \\
\text { industrialised nations }\end{array}$ & Rein and Shields & 2007 & 3 & 1 & 219 & 4387 \\
\hline 14 & $\begin{array}{l}\text { Definitions of place branding - Working } \\
\text { towards a resolution }\end{array}$ & Anholt & 2010 & 6 & 1 & 204 & 3884 \\
\hline 15 & $\begin{array}{l}\text { (Re)branding Amman: A 'lived' city's } \\
\text { values, image and identity }\end{array}$ & Khirfan and Momani & 2013 & 9 & 1 & 190 & 1333 \\
\hline 16 & $\begin{array}{l}\text { Place branding: Dilemma or } \\
\text { reconciliation between political } \\
\text { ideology and economic pragmatism? }\end{array}$ & Gertner & 2007 & 3 & 1 & 183 & 3659 \\
\hline 17 & $\begin{array}{l}\text { Turkey's EU accession as a question of } \\
\text { nation brand image }\end{array}$ & Kemming and Sandikci & 2007 & 3 & 1 & 161 & 3228 \\
\hline 18 & $\begin{array}{l}\text { From place marketing to place branding } \\
\text { and back }\end{array}$ & Govers & 2011 & 7 & 4 & 112 & 1345 \\
\hline 19 & Nation Branding in Asia & Anholt & 2008 & 4 & 4 & 106 & 2117 \\
\hline 20 & $\begin{array}{l}\text { The portrayal of Indigenous identity in } \\
\text { Australian tourism brand advertising: } \\
\text { Engendering an image ... }\end{array}$ & White and Pomering & 2011 & 7 & 3 & 84 & 1093 \\
\hline 21 & $\begin{array}{l}\text { Switzerland's nation branding initiative to } \\
\text { foster science and technology, higher } \\
\text { education and innovation: A case } \\
\text { study }\end{array}$ & Fetscherin and Marmier & 2010 & 6 & 1 & 73 & 1378 \\
\hline 22 & Brand Europe - Where next? & Anholt & 2007 & 3 & 2 & 70 & 1402 \\
\hline 23 & The media and national image & Anholt & 2009 & 5 & 3 & 45 & 891 \\
\hline Rank & $\begin{array}{l}\text { Article title (papers accessible only to } \\
\text { subscribers) }\end{array}$ & Author & Year & Volume & Number & $\begin{array}{l}\text { Quarterly } \\
\text { views }\end{array}$ & $\begin{array}{l}\text { Total } \\
\text { views }\end{array}$ \\
\hline 1 & $\begin{array}{l}\text { Measuring place brand equity with the } \\
\text { advanced Brand Concept Map (aBCM) } \\
\text { method }\end{array}$ & Zenker & 2014 & 10 & 2 & 985 & 1969 \\
\hline 2 & $\begin{array}{l}\text { The social revolution of place marketing: } \\
\text { The growing power of users in social } \\
\text { media campaigns }\end{array}$ & Ketter and Avraham & 2012 & 8 & 4 & 170 & 1363 \\
\hline
\end{tabular}


Table 1 (Continued)

\begin{tabular}{|c|c|c|c|c|c|c|c|}
\hline Rank & $\begin{array}{l}\text { Article title (papers that are/were } \\
\text { published in open access) }\end{array}$ & Author & Year & Volume & Number & $\begin{array}{l}\text { Quarterly } \\
\text { views }\end{array}$ & $\begin{array}{l}\text { Total } \\
\text { views }\end{array}$ \\
\hline 3 & $\begin{array}{l}\text { Branding the nation: Towards a better } \\
\text { understanding }\end{array}$ & Fan & 2010 & 6 & 2 & 165 & 2977 \\
\hline 4 & $\begin{array}{l}\text { Measuring success in place marketing } \\
\text { and branding }\end{array}$ & Martin and Zenker & 2011 & 7 & 1 & 117 & 1759 \\
\hline 5 & $\begin{array}{l}\text { Soft power: Power of attraction or } \\
\text { confusion? }\end{array}$ & Fan & 2008 & 4 & 2 & 116 & 2315 \\
\hline 6 & $\begin{array}{l}\text { From city marketing to city branding: } \\
\text { Towards a theoretical framework for } \\
\text { developing city brands }\end{array}$ & Kavaratzis & 2004 & 1 & 1 & 113 & 2258 \\
\hline 7 & $\begin{array}{l}\text { From image management to relationship } \\
\text { building: A public relations approach to } \\
\text { nation branding }\end{array}$ & Szondi & 2010 & 6 & 4 & 112 & 1785 \\
\hline 8 & $\begin{array}{l}\text { Cities and their brands: Lessons from } \\
\text { corporate branding }\end{array}$ & Kavaratzis & 2009 & 5 & 1 & 103 & 2058 \\
\hline 9 & $\begin{array}{l}\text { Unfolding and configuring two decades } \\
\text { of research and publications on place } \\
\text { marketing and place branding }\end{array}$ & Gertner & 2011 & 7 & 2 & 101 & 1407 \\
\hline 10 & $\begin{array}{l}\text { Dubai's brand assessment success and } \\
\text { failure in brand management - Part } 1\end{array}$ & Lee and Jain & 2009 & 5 & 3 & 97 & 1947 \\
\hline 11 & $\begin{array}{l}\text { Identity, image and brand: A conceptual } \\
\text { framework }\end{array}$ & Stock & 2009 & 5 & 2 & 80 & 1608 \\
\hline 12 & $\begin{array}{l}\text { The role of internal stakeholders in } \\
\text { destination branding: Observations } \\
\text { from Kerala tourism }\end{array}$ & Vasudevan & 2008 & 4 & 4 & 76 & 1517 \\
\hline 13 & $\begin{array}{l}\text { Lynch, Urry and city marketing: Taking } \\
\text { advantage of the city as a built and } \\
\text { graphic image }\end{array}$ & Hospers & 2009 & 5 & 3 & 75 & 1502 \\
\hline 14 & $\begin{array}{l}\text { Unravelling the complex relationship } \\
\text { between nationhood, national and } \\
\text { cultural identity, and place branding }\end{array}$ & Kubacki and Skinner & 2007 & 3 & 4 & 74 & 1486 \\
\hline 15 & $\begin{array}{l}\text { Creative dimensions for branding and } \\
\text { regeneration: Overcoming negative } \\
\text { perceptions of a city }\end{array}$ & Trueman et al & 2008 & 4 & 1 & 73 & 1462 \\
\hline 16 & $\begin{array}{l}\text { City branding and film festivals: Re- } \\
\text { evaluating stakeholder's relations }\end{array}$ & Ooi and Pedersen & 2010 & 6 & 4 & 72 & 1156 \\
\hline 17 & $\begin{array}{l}\text { Place branding: Evolution, meaning and } \\
\text { implications }\end{array}$ & Papadopoulos & 2004 & 1 & 1 & 70 & 1408 \\
\hline 18 & $\begin{array}{l}\text { Place marketing, place branding and } \\
\text { foreign direct investments: Defining } \\
\text { their relationship ... }\end{array}$ & Metaxas & 2010 & 6 & 3 & 68 & 1158 \\
\hline 19 & $\begin{array}{l}\text { Public diplomacy: Seven lessons for its } \\
\text { future from its past }\end{array}$ & Cull & 2010 & 6 & 1 & 66 & 1250 \\
\hline 20 & $\begin{array}{l}\text { Reimagining Singapore as a creative } \\
\text { nation: The politics of place branding }\end{array}$ & Ooi & 2008 & 4 & 4 & 63 & 1257 \\
\hline 21 & $\begin{array}{l}\text { Branding on ambiguity? Place branding } \\
\text { without a national identity: Marketing } \\
\text { post-conflict Northern Ireland in the } \\
\text { United States }\end{array}$ & Gould and Skinner & 2007 & 3 & 1 & 62 & 1234 \\
\hline 22 & $\begin{array}{l}\text { Liverpool One and the transformation of } \\
\text { a city: Place branding, marketing and } \\
\text { the catalytic effects of regeneration ... }\end{array}$ & Daramola-Martin & 2009 & 5 & 4 & 61 & 1220 \\
\hline 23 & $\begin{array}{l}\text { Marketing and managing nation branding } \\
\text { during prolonged crisis: The case of } \\
\text { Israel }\end{array}$ & Avraham & 2009 & 5 & 3 & 61 & 1210 \\
\hline 24 & $\begin{array}{l}\text { Nation branding: With pride against } \\
\text { prejudice }\end{array}$ & Widler & 2007 & 3 & 2 & 59 & 1175 \\
\hline 25 & $\begin{array}{l}\text { City branding: Can goods and services } \\
\text { branding models be used to brand } \\
\text { cities? }\end{array}$ & Parkerson and Saunders & 2005 & 1 & 3 & 56 & 1112 \\
\hline 26 & $\begin{array}{l}\text { The children's city - The transition from a } \\
\text { negative to a positive city image }\end{array}$ & Herstein and Jaffe & 2008 & 4 & 1 & 54 & 1077 \\
\hline 27 & $\begin{array}{l}\text { The World Heritage List: The making and } \\
\text { management of a brand }\end{array}$ & Ryan and Silvanto & 2009 & 5 & 4 & 49 & 988 \\
\hline
\end{tabular}

